\title{
Transgression: Human Desire and The Revelation of Homosexuality in Tom Stoppard's The Invention of Love
}

\author{
Wen-Hsiang Su
}

\begin{abstract}
Staying in or coming out of the closet have been two oppositional dissidences sanctioned by each of their supporters to stigmatize the legitimacy of the opposing stance. With these two discourses confronting each other, the public awareness of acknowledging the existence of homosexuality leads to the exposure of sexual repression. Thus, homosexuality not only overthrows the univocal disposition of heterosexuality, but also invokes a rising voice to challenge the doctrine in a conservative society. A.E. Housman, Tom Stoppard's protagonist in The Invention of Love, constrained by social convention, experiences a concupiscent desire for his classmate, Moses Jackson. Triggered by his indulgence in Greek poetry, from youth to death, Housman goes on the path in search of his real self. In this regard, this paper will focus on three stages, awareness, denial and acceptance, which influence Housman's whole life and delineate his inner struggle as he faces condemnation from society. With Stoppard's delicate arrangement of having the dead Housman meet the young Housman, homosexuality is turned into a polemical topic that deserves complete scrutiny.
\end{abstract}

Index Terms-Homosexuality, sexual repression, heterosexuality, Tom Stoppard, taboo.

\section{INTRODUCTION}

Compared with the rather tolerant morality at the beginning of the 17th century, the Victorian Era receded into a phase during which sexuality became a form of taboo. People felt confined and restrained from revealing or sharing sexual related activities for fear of violating the morality of the times. Verbal or physical sex-related activities "had no right to exist and would be made to disappear upon its least manifestation." [1] In other words, when it came to sex, silence was the rule. A person who talked about sex or even confessed his/her sexual dissidence would be condemned and considered morally violating the social taboo. With the ubiquitous oppression of sex during this era, sexuality became an aphrodisiac issue. The deployment of sexuality also led to the establishment of laws to repudiate intentional sexual behavior transgressions. Sexual repression and transgressive aesthetics were annexed to the rise of homosexuality. Thus, homosexuality was built on the theory of an extremely intimate relationship between members of the same sex, constructed on physical intimacy. That is to say, sex between two men or two women was regarded as transgressing the biological norm, namely sex only between a man and a woman. Normality was infinitely magnified to

Manuscript received February 20, 2017; revised April 25, 2017. This work was supported in part by Shih Chien University Kaohsiung Campus.

Wen-Hsiang Su is with the Department of Applied English, Shih Chien University Kaohsiung Campus, Taiwan (e-mail: whsu@g2.usc.edu.tw). eliminate the proliferation of discourse, so homosexuality was denied because of public ignorance. Under the surveillance and influence of heterosexual dominance, people feared the revelation of their sexual preference or even orientation. Homosexuality was undermined as dissidence straying from the social norm.

\section{HOMOSEXUALITY THEORY}

When it comes to homosexuality, sexuality deserves a lucid explanation and analysis. The subject of sex is embedded in human history. In certain cultures, people avoid talking about it and consider it a taboo. In other words, silence has ruled the understanding of sex. For fear of violating the moral conscience, people often choose not to expose their interest in the subject of sex. Michel Foucault once commented that "[i]f sex is repressed, that is, condemned to prohibition, nonexistence, and silence, then the mere fact that one is speaking about it has the appearance of a deliberate transgression." [2] Sex was intentionally made to disappear within the law of taboo. The fear of deviating from the social norm forced people to ambivalently refrain from mentioning sex or sex-related topics. Literally, the act of talking about sex was considered aphrodisiac, so is the behavior viewed as the alienation from the reach of power. The established law limits people's search for freedom and for the truth. However, talking about sex does not imply concupiscence, nor is it a crime to be judged. The foundation of a country relies on its population, which is completely based on how each individual makes use of sex. In fact, sex should not exist in the shadows because people talk about it more than anything else, whether unconsciously or intentionally. Sex is part of people's lives and they need to learn to embrace it as they chastise the archaic order. Not only is sex a matter of sensation and pleasure, it also indicates truth.

The nineteenth century was an age of various possibilities. Arbitrary truth was under scrutiny. Since sex had awakened from its repression, denouncing hypocrisy of sex as a taboo was the pivot when people started to deal with sex issues. To exploit its secret, people needed to understand it. As mentioned earlier, the future and fortune of a country relies on people's demeanor toward sex. Sex does not exist in one form but is perceived heterogeneously. In addition to the dispersion of sexualities, homosexuality simply happens to be one form that acts against the established law while representing heterogeneity. Foucault further commented that "homosexuality appeared as one of the forms of sexuality when it was transposed from the practice of sodomy onto a kind of interior androgyny, a hermaphrodism of the soul." [2] 
In terms of sexuality, homosexuality should not be excluded, as the issue of sexuality should not be neglected. Sexual sensibility constitutes homosexuality; in other words, masculinity and femininity can co-exist as inverted characteristics that determine a man's sexuality. This echoes Foucault's definition of androgyny when he tried to prove the existence of homosexuality as one species in the age of multiplication. Homosexuality should not be considered an indiscretion, but is the "means of access both to life of the body and the life of the species." [2] The more people choose to ignore the existence of homosexuality, the more unexpected vagaries people conjure up to delve into the core of its essence. In other words, homosexuality goes beyond sodomy, and indicates purely human desire.

As modern society is perverse, the desire embedded in each individual is systematically constrained because of social conventions and laws. People are forced to become blind and are silenced from expressing their desire. They keep this aphrodisiac desire in the depths of their hearts for fear of moral judgment. Thus, the law of marriage was conceived for governing sex. Through marriage, although sex is still not highlighted, it becomes less of a habitual sin but rather human nature. However, people still cannot avoid exposing themselves to the issue of sex; therefore, they justify their concupiscence as being morally acceptable in the name of marriage. Meanwhile, homosexuality is exclusive as its behavior could not be categorized, not to mention be sanctioned by the law of marriage in the $19^{\text {th }}$ century. Homosexuality, therefore, was denied and considered an abnormal sexual act. Foucault once said that " $[\mathrm{t}] \mathrm{o}$ deal with sex, power employs nothing more than a law of prohibition," which argues that homosexuality is displaced because of a power struggle. [2] Homosexuality was forced to disappear from the power vortex, but now it should also exist as a form of sexual desire. Power always comes after desire, and it constrains sex due to the social taboos, so truth is concealed. As an alternative form of sex, homosexuality resists the law of prohibition and demands the revelation of truth. In other words, homosexuality exists as a reverse discourse and requires attention to reveal its legitimacy. Judith Butler once stated that "biology is not destiny," which responds to the miscellaneous forms of sex. [3] She argued that sex should not become a mere method of confining the development of gender. As a passive medium, a human body will determine a cultural meaning for itself in order to fit into society. In this regard, homosexuality arises from homogeneous heterosexual and phallic cultural conventions based on its free will and unorthodox demeanor.

Homosexuality raises the issue of gender identification. As mentioned earlier, gender cannot be easily defined or referred to as the casual result of sex. In reality, one becomes a man or a woman as the result of a cultural compulsion. Since culture is the combination of linguistic structures and significations, it denotes that multiple identifications construct society, and " $[\mathrm{t}] \mathrm{he}$ 'unthinkable' is thus fully within culture, but fully excluded from dominant culture." [3] Specifically, gender is a complex issue which shifts at any given juncture in time. One's body acquires its signification by means of interacting with other entities. This interaction results in discourses governed by power relations. Sadly, homosexuality is deprived of its position in the context of power relations. Butler further commented that "no one is born with a gender-gender is always acquired." [3] Her meaning is that homosexuality only exists as a term to stabilize a binary opposition to heterosexuality. Power relations force homosexuality to retrieve internally as well as make it repressed and disparaged. Thus, homosexuality becomes an "Other," whose attached negative definition makes it come to terms with heterosexuality and gradually turns it into a sexual nonidentity. However, homosexuality is not a lack or an "Other" that "can never be possessed or completely understood." [4] What strikes people is not homosexuality itself, but the terror of the unknown that homosexuality engenders. It seeks to extend visibility and legitimacy as a ubiquitous discourse. Being a homosexual has never been easy, even in the $20^{\text {th }}$ century. Tom Stoppard's iconic character, A.E. Housman, in The Invention of Love suffers an inner struggle between being honest about his feelings toward Jackson and burying his agony as a gay man in his heart. Housman undergoes three phases, awareness, denial and acceptance, during his lifetime. This paper will focus on these three phases to decode Housman's transformation.

\section{STOPPARD'S THE INVENTION OF LOVE}

The play centers on A.E. Housman who died at the age of 77. When he stood on the bank of the river Styx to board the ferry to his afterlife, Housman began to reminisce about his life. Besides mentioning Housman's interest in Classics at Oxford, the play also reveals his relationship with and homosexual feelings for Moses Jackson. Growing from an immature young man into an intellectual scholar, Housman causes the ripple when interacting with the young Housman. The Invention of Love is "a memory play about A.E. Housman's unconsummated love for a charming young athlete he met when both were entering Oxford." [5] This becomes the focus for discussing the three phases of his life. Stoppard depicts Housman as an innocent young man who possesses "ardent love for classical literature and closeted passion for an Oxford classmate." [6] Housman confesses his true feelings while he is crossing the river Styx.

AEH. ... Oh, Mo! Mo! I would have died for you but I never had the luck.

CHARON. The dog?

AEH. My greatest friend and comrade Moses Jackson. [7]

This reveals Housman's inner struggle of accepting his homosexuality and revealing his identity to Jackson when studying together at Oxford. Katherine Kelly once commented that “A.E. Housman's inability to face up to and to act upon his true sexual nature brands him as indelibly Victorian," which explains why Housman forfeits sexual assertiveness and fidelity to himself. [8] He feels confined by the conventional law which prevents a man from showing feelings to another man. Housman himself also admits "[m]y life was marked by long silences." [7] This reconfirms his fear of violating the taboo, so he constructs his existence by means of repression and self-denial. His repressed feeling finds no outlet, but relies on classical literature concerning love of comrades as a way of escaping from the exposure of 
his true identity.

The title of this play, The Invention of Love, corresponds to homosexual love as, on the one hand, it is not approved by society; on the other hand, this type of love should be invented out of the fixed form of love that people are familiar with and acknowledge. Homosexuality needs to find a way out of the predetermined destiny of how a man loves a woman so as to lead to a happy ending. This play suggests that people need to invent themselves through the act of love in order to invent the object whom they love. On some level, because of his repression, Housman "internalized society's judge, converting his own guilt and shame into abject denial." [8] It is never about whether Jackson accepts Housman's homosexual love, but about his emotional anxiety from his denial of being a homosexual. Sadly, Housman only expresses his romantic sensibility through poetry; as a man in love with another man, he fails to come out of the closet. According to Eve Kosofsky Sedgwick, "[t]he closet is the defining structure for gay oppression in this century," which means the image of the closet is initiated by the speech of silence. [9] Set as a confinement, the closet becomes a shelter to hide all of the secrets so they cannot be discovered. Only be keeping his true love from Jackson can Housman regain his sense of security. As mentioned earlier, when Foucault explained that silence was the rule in terms of sexuality, and Butler concluded that gender has no arbitrary relationship to one's sex, they both believed that the existence of homosexuality is responsive to the incoherence and contradictions of heterosexuality. Obviously, homosexuality and heterosexuality cannot be viewed as two oppositional discourses; rather, they both come from power. Power forces most people to overlook the existence of homosexuality because of its mystery and its deviation from the norm. Eventually, resistance is the consequence of the revelation of homosexuality. Foucault said that "[w]here there is power, there is resistance." [2] Considered an 'Other,' homosexuality just happens to resist psychologized homophobia secularized by heterosexual entitlement.

At the beginning of the play, Stoppard explains that the multiplicity of identities proves the existence of homosexuality as a possible discourse that deserves a place in society. When Housman introduces himself to Charon, Stoppard uses the idea of multiple identities to suggest embracing one's otherness.

CHARON. A poet and a scholar is what I was told.

AEH. I think that must be me.

CHARON. Both of them?

AEH. I'm afraid so.

CHARON. It sounded like two different people. [7]

Here, Charon represents a conventional norm that forbids the appearance of any possible deviation from its control. When asking "both of them," Charon shows a sense of uncertainty about something he could not handle. Charon assumes one person can only be associated with one identity. Nevertheless, Housman, after he dies, completely accepts his double identities, or even multiple ones when replying "Alfred Housman is my name. My friends call me Housman. My enemies call me Professor Housman." [7] In his afterlife, he finally emancipates himself from the shackles of social order and embraces his homosexuality. This introduces the initiation of how he transforms from a man refusing to accept his homosexuality to one who loves who he really is. When he studies at Oxford, Housman feels confined by the social law that condemns homosexuality as "a religious profanation" and "an amorous equivocation." [10] Although he knows he loves Jackson, Housman could not boldly express his feelings for fear of the public intolerance. The power of heterosexuality dominates society, so Houseman cages himself in his own world and turns into "a figure haunted by grief, grief resulting from his hopeless love for his athletic friend." [11] Stoppard understands the intellectual and emotional pains this world causes to repudiate any form of abnormal sexuality. It, of course, makes sense that Housman relates his pain to the intolerance of homosexuality and his renunciation of his homosexual love.

The more Housman tries to ignore his inner voice of falling in love with Jackson, the more agony and suffering he sustains. Though knowing his love to Jackson is beyond friendship, Housman intends to avoid the issue of homosexuality by justifying his love as a form of brotherhood. When the young Housman meets the dead Housman, he shares with him his interest in the stories of Theseus and Pirithous, and Achilles and Patroclus to claim that he is not a gay man. The young man believes that his love of Jackson shares some similarities with that among those heroes and he does not understand why he cannot show his real affection for Jackson and why people do not try to understand him. This is the very first time that the young Housman is aware of his love for a man. The young Housman even asks " $[w]$ as there ever a love like the love of comrades ready to lay down their lives for each other" to exemplify that his love is not a homosexual act. [7] He further explains that: "Theseus and Pirithous. They were kings. They met on the field of battle to fight to the death, but when they saw each other, each was struck in admiration for his adversary, so they became comrades instead and had many adventures together ... They loved each other, as men loved each other in the heroic age, in virtue." [7] Housman would not refer his concern for Jackson to a homosexual relationship. Mentioning the stories of these heroes suggests Housman's awareness of his homosexuality and, at the same time, his denial of it. He has the need to justify his behavior, so he says that he would have died for Jackson but never had the chance to do so. Housman's era does not allow or accept him to commit homosexuality so that "his homosexual desire was accompanied by, and for this perhaps required, this internal differentiation." [12] He knows that his affection for a man cannot be conceived as natural, and the stigma of homosexuality forces him to internalize his real sexual orientation to succumb to an oppressive discourse of heterosexuality. Talking about these two kings helps Housman to unlock his doubts about violating the social order. By doing so, he gains a sense of security to protect his secret of loving Jackson from being exposed to public castigation and being scrutinized by the public.

After the first phase of recognizing his love for Jackson, Housman moves to his second phase of denying his homosexuality. When he mentions Theseus and Pirithous, he in fact acknowledges his special feelings for Jackson; 
meanwhile, for fear of being considered abnormal, he needs to hide his affection. He refuses to be tagged a gay man after his friends know that he is interested in Greek poems. Under the influence of heterosexual expectations, Housman understands that his interest will force him to step out of his closet because "[w]ell, to a Roman, to call something Greek meant . . . sissylike, or effeminate." [7] He denies that his feelings towards Jackson are a form of homosexuality. While he loves Greek poems, Housman strives to avoid the stereotype of any connection between Greek poems and his homosexuality. As a matter of fact, he undergoes a series of inner struggles between being true to himself and hiding in the dark to keep his secret. He seems to forget that "the disclosure of one's inner self and desires does not lead to great self-acknowledgement, but merely imbricates the subject further in a network of disciplinary power relations." [13] Housman forgets that sexuality and power are related and coextensive. Where there is desire, the power relation is submerged. Housman's desire comes from his affection for Jackson, which is considered abnormal and twisted by society. He needs to protect himself from being wrongly recognized as a gay man, and wants to gain the approval of society for his admiration for rather than love of Jackson. Butler argued that "sex is a political and cultural interpretation of the body." [3] This argument indicates that sex and gender do not have an arbitrary relationship, so Housman's relationship with Jackson is not a pathological disease that stands for an oppositional status competing with heterosexuality. Under the dominance of the hegemonic order, Housman needs to yield his free will to comply with the social order. Housman admits that "I know very well there are things not spoken of foursquare at Oxford. The passion for truth is the faintest of all human passions. In the translation of Tibullus in my college library, the he loved by the poet is turned into a she." [7]. His confession shows his subordination to the social order, and it forces him to return to his safety zone. Since homosexuality is a social taboo, he finds no reason to break it. His inwardness prevents him from honestly accepting who he really is.

Housman's denial in the second phase starts from the time when Jackson rejects him. Housman makes a hand-made laurel crown to celebrate Jackson's success on the track. However, Jackson refuses the crown and leaves it on the seat, leaving without saying a word or showing any gratitude to Housman. Besides showing his homophobic attitude to homosexuality, Jackson's decision not to accept the crown indicates his rejection of Housman in terms of men's love. This enables Housman to return to his closet without making any indicative move towards Jackson. Although aware of his love for Jackson, Housman has no choice but to deny his real feelings for him for fear of losing him and suffering judgment from society. We then notice that the relationships of homosexuality and heterosexuality are intertwined. As the conversation between Housman and Jackson shows:

JACKSON. The girls were pretty, and the tunes, it was only the story.

HOUSMAN. That whole thing was silly.

JACKSON. Jolly, you said. You don't have to agree with me all the time.

HOUSMAN. I don't
JACKSON. Well, you do, you know. Hous-you should stick to your own opinions more. [7]

This short talk explains that Housman needs to try his best to hide his feelings. In fact, he unconsciously agrees with Jackson in every aspect. When Jackson says, "You don't have to agree with me all the time," it implies that he has already noticed that Housman has a special feeling for him. Meanwhile, Housman's response, "That whole thing was silly," indicates that he does not like Jackson to focus on women. Besides, when Housman replies "I don't," it can be perceived that he seems to have been caught doing something wrong and feels anxious, so he denies what he just did. Once again, we can see his desire revealed when Housman encounters Jackson. Interacting with Jackson exposes Housman's inner desire long confined by the social order, and he strives to repress it in order not to be found out. However, he seems to forget that "[s]ince the unlived life is frequently the object of a desire that remains repressed or at least unfulfilled, the desire will continue to exist, seeking some sort of outlet or expression." [14] In order not to be tagged as "Other," Housman ignores his inner voice but complies with the main stream. Fear of being punished forces him to deny his homosexuality and to internalize his unspeakable affection for a man in his heart. However, Housman should have embraced his true identity in order to liberate his confined soul from the shackles attached by both Jackson and society. What Jackson says at the end of this conversation suggests that Housman should reclaim his own power as an independent discourse free of any judgment and discrimination.

In Housman's second phase of denying his homosexuality, Chamberlain, one of his classmates, who admits his homosexual orientation to Housman, is introduced as an oppositional figure against the expectations of society as well as an inspiration to help Housman look at his chaotic life. The Chamberlain's mission is to manifest the existence of a gay man surviving the repressive nature of society and the social censorship. Chamberlain proves his value as a complete discourse, not subordination. He could not endure seeing Housman suffering due to his love for Jackson while he watches him deny his gay identity.

CHAMBERLAIN. Sit down, you're like a nervous girl . .

No offence, old chap. I like you more

than

anyone I know. I even like you for the way you stick to Jackson. But he'll never want what you what. You'll have to find it somewhere else or you'll be unhappy, even unhappier. [7]

In this short statement, Chamberlain suggests that Housman put himself before anyone else and learn to love himself first. Loving Jackson with fear has made Housman lose his own autonomy. Chamberlain believes that Houseman should learn to accept his own identity in order to love other people. He sees Housman suffering because of his homosexual identity and because of his refusal to accept the fact that he loves a man. Under the dominance of the social order, Housman feels confined, which undermines the importance of his existence as a man who loves another man. 
As a matter of fact, "homosexuality and heterosexuality mutually define each other." [15]. This demonstrates that heterosexual and homosexual desire mutually manifest each other in terms of sexuality. To be frank, both homosexual and heterosexual desires are conceived as a fundamental aspect of the inter-relatedness with other people. With this interaction, the significance of each sexual orientation is highlighted. Homosexuality is no longer repressed, but is juxtaposed, making it as important as heterosexuality in regard to sexuality. People engaging in same-sex relationships are empowered to justify their deviant behavior which is misunderstood by the public. The belief that " $[\mathrm{t}] \mathrm{o}$ live openly as a lesbian or gay man is to depart from society's predominantly heterosexual expectations" turns into dissidence. [16] What Housman lacks is a transgressive aesthetic resolution to acknowledge and respect his deviation from the social order. He should have stopped denying his affection for a man and come to accept his true identity as a gay man.

Chamberlain plays the role of guiding Housman to gradually embrace his gay man identity. As an openly gay man, Chamberlain is fully aware that "telling others about their sexual orientation could change the power dynamics within a particular environment and the relationship they had with the individuals they told." [17] Housman undergoes the suffering between the moral principle and his own conscience. Losing a dynamic stand in society bothers Housman while also jailing him in his own closet. His denial only manifests his craving for the love in Greek love poems like those heroic figures sharing an intimate brotherhood. Housman's inward attitude limits his development to properly express his love to Jackson. Chamberlain sees Housman's agony whenever he faces Jackson.

CHAMBERLIAN. Nothing which you'd call indecent, though I don't see what's wrong with it myself. You want to be brothers-in-arms, to have him to yourself . . . to be shipwrecked together, (to) perform valiant deeds to earn his admiration, to save him from certain death, to die for him — to die in his arms, like a Spartan, kissed once on the lips ... You want him to know what cannot be spoken ... [7]

Chamberlain explains that only through accepting his real identity can Housman liberate himself to love. He finds that Housman feels ashamed of his identity and beautifies his love through Greek poems. In other words, Housman lives in his own created world where he believes Jackson will love him back some day like the heroic Greek heroes. However, Housman's ideal love story does not provide him with a perfect ending because he seems to forget that "homosexuality was an inborn trait and posited the existence of a third sex." [18] Therefore, he could not ignore his sexual orientation when expressing his love for Jackson. In his love of Jackson, he sacrifices himself in many ways in order to receive his recognition. Love is not constructed on how much you love the person, but on how that person accepts your true identity. The more Housman strives to win Jackson's recognition, the more failures he encounters. All dissatisfactions result from the fact that he fails to escape the confinement imposed by the moral social order. Chamberlain's role contributes to Housman's liberation through unmasking the disguised and systematic domination.

For fear of being morally scrutinized, Housman maintains his love of Jackson not only in Greek poems but also in his heart. He hopes that Jackson will understand that their friendship is more than what it appears. By introducing those heroic figures, he is meant to find comfort to comply with his homosexuality. Hiding in the closet hinders Housman's free will to openly accept himself as a gay man. Instead of embracing more promiscuous sexuality, Housman "nursed a single, unrequited love for his class mate Moses Jackson" and "poured his stifled ardor into his poetry and scholarship." [19] Apparently, Housman runs away from the truth that would enable him to live a freer life. He chooses to neglect it and to repress his feelings as well. Evidence that shows Housman's denial of his homosexuality comes in the talk with Jackson. The conversation focuses on Jackson's girlfriend Rosa who suspects that Housman has feelings for Jackson.

JACKSON. Rosa said you're sweet on me.

HOUSMAN. What did she mean?

JACKSON. Well, you know.

HOUSMAN. What did you say?

JACKSON. I said it was nonsense. We're chums. We've been chums since Oxford, you me, and Pollard. [7]

We can see two different ideologies interacting with each other in this short talk. On the one hand, Jackson notices that the way Housman treats him is quite extraordinary, and more than as a friend. When responding, "Well, you know," Jackson seems to imply that he knows about Housman's homosexual affection for him but he cannot confront him for fear of breaking the taboo. Later on, in order not to make the conversation awkward, Jackson immediately confirms his pure friendship with Housman, even by mentioning another friend to assure him that a homosexual relationship will not develop between them. Here, Jackson's reaction corresponds to "heterosexuality as a fear of male homosexuality." [15] The systematic social order not only becomes a threat to homosexuality but also intimates that heterosexuality is involved in any form of relationship. On the other hand, Housman's two consecutive questions suggest that he has been waiting for Jackson's answer regarding whether he will accept his love or not. In fact, Housman does not care what Rosa thinks of him; he is more anxious to see Jackson's reaction to knowing his identity as a gay man. After he hears Jackson's answer, the story has another ending.

\section{JACKSON. She didn't talk about Pollard. You're not, are you, Hous?}

HOUSMAN. You're my best friend.

JACKSON. That's what I said, like ...

HOUSMAN. Theseus and Pirithous.

JACKSON. The Three Musketeers. [7]

Housman finally realizes that they are not on the same page. Jackson only likes Housman as a friend, so mentioning the Three Musketeers helps him stop Housman from creating a homosexual relationship from their friendship. The image 
of the Three Musketeers can represent a real friendship, whereas Housman's two heroic kings imply something more than brotherhood, or bromance. Housman wants to build up the relationship with Jackson to be like that of the two kings so as to cover up the fact that he is a gay man. When Housman comes to the second phase of denial, he fails to accept his homosexuality. Housman strives to justify his love of Jackson in terms of the stories he learned in the Greek poems, instead of acknowledging his homosexual love of a man. Why Housman denies himself in the second phase originates from a lack of confidence. He spends all his life complying with Jackson as well as regretting his disapproved love of a man. If he cannot love himself, how could he have the right to ask Jackson to love him back, regardless of the fact that Jackson is a straight man?

At the very beginning, Stoppard already indicates that Housman will go through three phases in his life as his plot "does allow for moral choice." [20] When Housman comes back to meet his young self, it suggests that he finally embraces the truth and accepts his homosexuality. Through many ideological confrontations with Jackson and inner struggle with the social order, although he dies in the end, Housman eventually takes the road that he had previously refused to take.

JACKSON. What will become of you, Hous? HOUSMAN. It has become of me. [7]

Interestingly, the intention of Jackson's question of Housman can be concluded as his concern for Housman as a friend, and as his suspicion of Housman's sexual orientation. The latter becomes the pivot that Jackson uses to confront Housman. Jackson stands for the social order, scrutinizing any deviation from the mainstream. In addition, Jackson shows his concern about being threatened by the eccentric relationship Housman has created with him. People's reaction to something they do not understand results in repulsive repugnance. Thus, after questioning Housman, Jackson takes off the laurel crown that Housman made for him to show his displeasure with his misbehavior. Another dialogue explains Jackson's discomfort with being involved in a homosexual relationship.

JACKSON. Mention that perhaps you shouldn't get to be pal with him too much, it may be misunderstand.

HOUSMAN. You think Chamberlain is sweet on me? JACKSON. No, of course not. But one has heard things about

Chamberlain at the office. I'm sorry now I mentioned him! I know I'm all hobnails but you're all right about it, aren't you, Hous? You see, I'm awfully strong on Rosa, she's not like other girls, she's not what I'd call a girl at all, you saw that for yourself, she's a woman, we love each other. [7]

First of all, Jackson suggests that Housman keep his distance from Chamberlain because he, like others, believes homosexuality is infectious. Jackson considers that a gay man like Chamberlain is not a blessing and people will make negative comments. Secondly, Jackson's obnoxious viewpoints explain that "people can tolerate the pleasure, but they can't accept the happiness." [1] When it comes to sexuality, heterosexuality seems to have the privilege of claiming itself to be an authentic love. Love other than this kind is considered transgression and indiscretion. Moreover, Jackson brings up his love for Rosa to prove that heterosexual love is the norm that Housman should be pursuing. Jackson simplifies sexuality by suggesting " $[\mathrm{m}] \mathrm{en}$ born with feelings of same sex desire, congenital inverts, could easily become diseased through lack of self-control." [21] The suggestion he offers Housman implies that he should control his desire so as not to love or show any affection to a man. Same-sex desire or homosexuality results in an abrogation of self-control. As long as Housman learns to control himself, he could enjoy love as a "normal" man. However, the misconception of heterosexuality maintaining a more sacred love does not make Housman abide by the social order in the end.

The title of the play denotes that Housman's love for Jackson will not have a happy ending, especially after Jackson knows that Housman is a gay man. As mentioned earlier, Jackson uses an arbitrary scope to evaluate Housman's existence and value after the truth is revealed. As a straight man, Jackson defends himself as being free of responsibility of forcing a gay man to hide in the closet. 'Seeing is believing' is wrongly used through the scope of a heterosexual eye. The reason could be concluded that homosexuality is almost always considered a threat to the existence of heterosexuality in terms of a power struggle. Butler once said that "all social systems are vulnerable at their margins, and that all margins are accordingly considered dangerous." [3] This suggests that heterosexuality feels threatened because of the awakening of homosexuality, which has been representing a margin in the power struggle. Once menaced, heterosexuality loses its affirmative ground of expressing its pivotal thought. Jackson's reaction to Housman's sexual orientation explains it all: "How could I know? You seem just like . . . you know, normal . . . How could I know?!" [7] "How could I know" becomes an excuse for Jackson to be free of his redemption. Therefore, homosexuality is viewed as the homophobic signifying dominance. Considered a reversed discourse, homosexuality needs to demand its legitimacy and find its way out of the hegemonic control. When Housman says "I didn't get what I wanted, that's true, but I want what I've got," it indicates that he has realized the urgency to accept himself as a gay man in order to free his confined soul. [7] He starts to esteem the importance of his personal value and his identity as a gay man once Chamberlain gives him a lecture on homosexuality

CHAMBERLAIN. ... .We belong to a sort of secret society ... Actually it's more like a discussion group. We discuss what we should call ourselves. 'Homosexuality' has been suggested.

AEH. Homosexuality?

CHAMBERLAIN. We aren't anything till there's a word for it.

AEH. Homosexuality? Who is responsible for this barbarity? CHAMBERLAIN What's wrong with it?

AEH. It's half Greek and half Latin!

CHAMBERLAIN. That sounds about right. [7]

Chamberlain is meant to say that being a gay man is not 
shameful. A gay man deserves a name to justify the fact of also being an integrated man just as a straight man is. Heterosexuality undermines the significance of homosexuality, but "[h]omosexuality, then, would seem to be a matter of nature, not nurture; fate, not free will." [22] One man has no right to deprive the existence of another. Thus, Chamberlain claims the importance of being honest to oneself as well as to his loved one. In addition, when responding to Housman's question of the hybridity of the word, homosexuality, Chamberlain reassures him of the authenticity of homosexuality by implying that sexuality should not be classified into any category because of its uniqueness. The combination of half Greek and half Latin explains the innate trait of a gay man: a biological man who mentally loves another man. This suggests that homosexuality should not be attached with any fixed meaning, so one's sexuality is always changing. Thus, Housman should not be so surprised to know that he had really fallen in love with a man, and his situation is completely different from those heroic figures in Greek poems. Chamberlain encourages Housman to accept the fact of being a gay man and that he should not feel ashamed of it.

The third phase, acceptance, is significant for Housman. He not only accepts the fact that he is a gay man, but also knows that Jackson will never acknowledge his love. Thus, that explains why, when he comes back to meet his young self, Housman comes to the awareness of the zero possibility of ending up with Jackson by telling the audience "the love poem had to be invented." [7] This implies that his love for Jackson is twisted in the eye of the public, so he could not have a blessed love like other love stories written in history. Accordingly, his love for Jackson should be specially made; in other words, Housman should create his own version of love compared to heterosexual love. He realizes that "'homosexual' is not the antithesis of the 'heterosexual' but 'a subversion of the quasi-sexual." [18] Now, he learns to be proud of his true identity and to stop hiding from the exposure of being a gay man because "knowledge of his body and his desire signified power." [24] Being a gay man is absolutely not a crime, nor a disgrace that should haunt a man for life. Homosexuality is misunderstood in terms of its legal identity and legitimacy. Its assumed crime comes from repugnant indecency and abomination. Only through embracing his true self can Housman liberate himself to have the ability to love. Gleeson once commented that "everyone is capable of making homosexual object choice," which indicates that one should freely choose whomever he loves after he learns to accept who he really is. [24] This also corresponds with the idea mentioned earlier: the word, homosexuality, is a hybrid, which offers miscellaneous characteristics that should not have a fixed meaning. When Housman says "I shook his hand and tore my heart in sunder," he is aware that he needs to give up his love for Jackson and to begin to love himself more. Jackson's reaction to Housman's homosexual identity implies "[c]onfession is an act of violence against the unoffending." [7] This explains the unjust treatment deployed by the heterosexual dominance to limit the development of homosexuality for fear of being replaced in terms of power.

\section{CONCLUSION}

Sexuality is constantly changing and it should not be adopted as a law to enforce some norms and expectations through power. Both heterosexuality and homosexuality are derived from a perpetual impulse that comes from the pleasure of the human body. Each side represents a discourse that conveys social, political and cultural significance and forms various ideas and concepts to show the miscellaneous alternatives. Therefore, there should not be any abnormality when it comes to homosexuality. At the end of the play, when Housman states "[m]y life is marked by long silences," this suggests that he has been manipulated by the heterosexual ideology of not talking about his sexual orientation. [7] The arrest of Oscar Wilde in the play also denotes the awakening of a transgressive aesthetic ready to challenge the established norm. The acceptance of being a gay man consummates Housman's wholeness and helps him to avoid discrepant scrutiny. Housman has been denying himself because of Jackson's rejection of his love. He quotes the last line in Douglas' poem: "I am the love that dare not speak its name" to show his regret. [7] Housman admits that he is not brave enough to accept who he really is, so he has been hiding himself in the darkness for fear of getting hurt. However, staying in the closet does not ease his pain. He suffers each day not only because of Jackson's rejection but also because of his secret. The more Housman strives to deny his sexual orientation, the more the agony rebounds on him. Wilde's news drives Housman's transformation because "[t]ruth is quite another thing and is the work of the imagination." [7] Housman realizes the importance of being himself instead of pleasing Jackson. The truth is buried and misplaced as imagination is forbidden from society. Imagination represents an "outlaw" that cannot cope with the mainstream. The problem is not imagination but the system that confines people's thoughts. Homosexuality is a form of exception that goes beyond the control in a world full of mostly heterosexuals. People are afraid of what they do not know, and feel panic when faced with change. However, people seem to forget that one's sexuality is changing all the time, so homosexuality should not be considered an abnormal pleasure but a discourse sharing the same significance as heterosexuality.

Stoppard adopts the image of Wilde at the end of the play to illustrate the alternative embedded in society. Wilde functions as an imperative icon that makes people reevaluate their preconceptions as well as their misunderstanding of homosexuality. According to postmodernism, no subject should be alienated, and authenticity no longer belongs to a particular discourse. Homosexuality is an independent discourse not made for competing with heterosexuality, but rather "heterosexuality needs homosexuality for its own definition: a macho homophobic male can define himself as 'straight' only in position to that which he is not-an effeminate gay man." [25] Homosexuality is an assertion of heterosexuality. Housman's achievement in his third phase of embracing his homosexuality denotes his striving for a social position within natural differences. The three phases, awareness, denial, and acceptance, construct his integrity. Stoppard manages to let Housman experience the toughest time in order to manifest the value of homosexuality. In this 
regard, Housman successfully "throws off the shackles of political correctness and explores the complexities of sexual attractions." [26] Homosexuality is not only identity politics but also a representational process to which value is attached to it. Furthermore, Housman overturns the entire systematics of the natural and the unnatural. Foucault once commented that "[i]t is through sex ... that each individual has to pass in order to have access to his own intelligibility ... to the whole of his body . . . to his identity." [2] This explains the significance of Housman's transformation through the three phases of his life. In his last monologue, he says "[h]ow lucky to find myself standing in this empty shore, with indifferent waters at my feet.'[7] We could understand that although he has been through a lot in life, he has finally freed his soul to embrace both the happiness and bitterness that have haunted him until death. He used to be negative about everything that happened to him, especially his homosexual love for Jackson. However, he reclaims his own identity, and his indifference to his death indicates his victory over his own sorrow and timidity. Foucault further emphasized that " $[\mathrm{w}] \mathrm{e}$, on the other hand, are in a society of 'sex,' or rather a society 'within a sexuality" (147). This explains that sex has no norms and should not be used to set up intrinsic rules either. The Invention of Love offers readers a chance to reevaluate the conception of homosexuality. There should be no criteria for classification when it comes to sexuality, no matter whether hetero-, homo-, or even bisexual. Sexuality should not be a taboo, nor should homosexuality.

\section{REFERENCES}

[1] M. Foucault, "The gay science," Critical Inquiry, vol. 37, no. 3, pp. 385-403, 2011

[2] M. Foucault, The History of Sexuality, New York: Vintage Books, 1990.

[3] J. Butler, Gender Trouble: Feminism and the Subversion of Identity, New York: Routledge, 1999

[4] M. L. Ellis, "Homophobia is the patient," Psychodynamic Practice, vol. 14, no. 3, pp. 313-24, 2008.

[5] R. Hornby, "Memories," The Hudson Review, pp. 464-470, 2001.

[6] B. Mondello, “'Love' has 2 faces," American Theatre, pp. 76-78, 2001.

[7] T. Stoppard, The Invention of Love, New York: Grove Press, 1997.

[8] K. Kelly, The Cambridge Companion to Tom Stoppard, Cambridge: Cambridge University Press, 2001.

[9] E. K. Sedgwick, Epistemology of the Closet, Berkeley: University of California Press, 2008.

[10] G. Cutting, The Cambridge Companion to Foucault, New York: Cambridge University Press, 1994.

[11] W. Emilsson, "Living at the turning point of the world: Stoppard and Wilde," ESC, vol. 29, no. 1-2, pp. 131-148, 2003.
[12] J. Dollimore, Sexual Dissidence: Augustine to Wilde, Freud to Foucault, Oxford: Oxford University Press, 1991.

[13] L. McNay, Foucault: A Critical Introduction, Cambridge: Polity Press, 1994.

[14] B. Niederhoff, "Unlived lives in Kazuo Ishiguro's The Remains of the Day and Tom Stoppard's The Invention of Love," Connotations, vol. 20, no. 2-3, pp. 164-188, 2010-2011.

[15] S. Marcus, "Queer theory for everyone: A review essay," Sign, vol. 31, no. 1, pp. 191-218, 2005.

[16] C. Crabtree, "Rethinking sexual identity," Existential Analysis, vol. 20, no. 2 , pp. 248-261, 2009

[17] M. Narui, "Understanding asian/american gay, lesbian, and bisexual experiences from a poststructural perspective," Journal of Homosexuality, vol. 58, pp. 1211-1234, 2011.

[18] G. Drazenvovich, "A Foucauldian analysis of homosexuality," Educational Philosophy and Theory, vol. 44, no. 3, pp. 259-275, 2012.

[19] L. A. Livingston, "To be said to have done it is everything': The theatrical Oscar Wilde and possibilities for the (re)construction of biography," A/B: Auto/Biography Studies, vol. 24, no. 1, pp. 15-33, 2009.

[20] M. Meisel, "The last waltz: Tom Stoppard's poetics of science," Wordsworth Circle, vol. 38, no. 102, pp. 13-19, 2007.

[21] C. Upchruch, "Liberal exclusions and sex between men in the modern era: Speculations on a framework," Journal of the History of Sexuality, vol. 19, no. 3, pp. 409-431, 2010

[22] E. T. Armour, "Building me with (queer) science: Religion, sexuality, and (post?) modernity," International Journal for Philosophy of Religion, vol. 68, no. 1/3, pp. 107-119, 2010.

[23] J. Davidson, "Dover, foucault and greek homosexuality: Penetration and the truth of sex," Past \& Present, vol. 170, pp. 3-51, 2001.

[24] K. Gleeson, "Discipline, punishment and the homosexuality in law," Liverpool Law Review, vol. 28, pp. 327-347, 2007.

[25] K. Namaste, "The politics of inside/out: queer theory, poststructuralism, and a sociological approach to sexuality," Sociological Theory, vol. 12, no. 2, pp. 220-231, 1994.

[26] B. Cossman, "Sexuality, queer theory, and 'feminism after': Reading and rereading the sexual subject," McGill Law Journal, vol. 49, no. 4, pp. 849-876, 2004

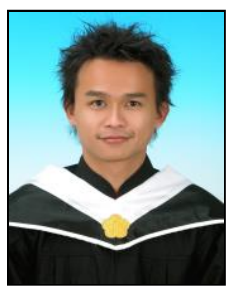

Wen-Hsiang Su was born in Tainan, Taiwan. Wen-hsiang received the following degrees: bachelor of arts in English literature from National Sun Yat-sen University, Taiwan, in 2000; he received his master of arts in English literature from Sun Yat-sen University, Taiwan, in 2004; he received his Ph.D. of arts in English literature from National Kaohsiung Normal University, Taiwan, in 2011. His major field of study is drama, minor in fiction. He is now an assistant professor at Shih Chien University Kaohsiung Campus in Taiwan. His publications included "A Critical Study of John Fowles' The Collector," Journal of Chien-Hsin University, vol. 33, no. 1, pp. 75-84, 2013; "Dead End: An Analysisof Characters in Tom Stoppard's Rosencrantz and Guildenstern Are Dead," Kaohsiung Normal University Journal vol. 35, pp. 93-108, 2013; "Katherina's Transformation and its Impact in Shakespeare's The Taming of the Shrew," Journal of Humanities and Culture Studies R\&D, vol. 2, no. 1, pp. 1-14. At present, he is working on boys' love (BL) fiction. 